\title{
The use of Nano-Gro biostimulant and stubble catch crop as a plant-health factor in winter wheat continuous crop
}

\author{
Wykorzystanie biostymulatora Nano-Gro i międzyplonu ścierniskowego \\ jako czynnika fitosanitarnego w monokulturowej uprawie pszenicy ozimej
}

\author{
Danuta Parylak*, Elżbieta Pytlarz
}

\begin{abstract}
Summary
One-factorial field experiment was conducted in 2010-2013. The aim of the study was to evaluate the usefulness of Nano-Gro biostimulant and stubble catch crop in reducing the occurrence of stem base diseases of winter wheat growing in continuous crop under traditional or reduced post-harvest and pre-sowing tillage and the influence of these factors on wheat productivity. The significantly higher infection of stems and roots of winter wheat growing in continuous crop as well as the decrease in grain yield by $12.3 \%$ were observed in relation to crop rotation. In plowing system the seed-dressing with Nano-Gro biostimulant and the combined use of that product with the annual plowing down stubble catch crop of white mustard significantly reduced the infection of stem base respectively by 28.7 and $21.9 \%$ compared with monoculture without regenerative practices. After tillage simplification stem base diseases reduction (by 17.5\%) were found only after plowing down biomass of catch crop. The degree of the root system infection generally did not depend on tillage and regenerative practices but there was significant correlation between grain yield and index of root infection.
\end{abstract}

Key words: winter wheat; monoculture; biostimulant; stubble catch crop; stem base diseases; yield

\begin{abstract}
Streszczenie
Jednoczynnikowe doświadczenie polowe zrealizowano na bazie ścisłego doświadczenia w latach 2010-2013. Celem badań była ocena przydatności biostymulatora Nano-Gro oraz przyorywanego międzyplonu ścierniskowego w ograniczaniu występowania chorób podstawy źdźbła pszenicy ozimej uprawianej w monokulturze oraz wpływu tych czynników na produkcyjność pszenicy w warunkach tradycyjnej lub uproszczonej pożniwnej i przedsiewnej uprawy roli. Wykazano istotnie większe zainfekowanie źdźbeł i korzeni pszenicy ozimej uprawianej w monokulturze oraz obniżkę plonu ziarna o 12,3\% w stosunku do płodozmianu. W systemie płużnym zaprawianie ziarna biostymulatorem Nano-Gro oraz łączne stosowanie tego preparatu z corocznym przyorywaniem międzyplonu ścierniskowego z gorczycy białej przyczyniło się do istotnej redukcji porażenia podstawy źdźbła odpowiednio o 28,7 i 21,9\% w porównaniu z monokulturą bez zabiegów regeneracyjnych. Po uproszczeniu uprawy roli ograniczenie porażenia podstawy źdźbła (o 17,5\%) stwierdzono wyłącznie po wprowadzeniu do gleby biomasy międzyplonu. Na stopień zainfekowania systemu korzeniowego na ogół nie miał wpływu sposób uprawy roli i zabiegi regeneracyjne, stwierdzono natomiast wyraźną zależność plonu ziarna od stopnia porażenia korzeni pszenicy.
\end{abstract}

Słowa kluczowe: pszenica ozima; monokultura; biostymulator; międzyplon ścierniskowy; choroby podstawy źdźbła; plon

\footnotetext{
Uniwersytet Przyrodniczy we Wrocławiu

Katedra Kształtowania Agroekosystemów i Terenów Zieleni

PI. Grunwaldzki 24A, 50-363 Wrocław

*corresponding author: danuta.parylak@up.wroc.pl
} 


\section{Wstęp / Introduction}

Specjalizacja w rolnictwie doprowadziła do ograniczenia nakładów związanych z konwencjonalną uprawą roli oraz do wzrostu udziału roślin zbożowych $\mathrm{w}$ zmianowaniu (Starczewski i wsp. 2004). Koncentracja kłosowych w strukturze zasiewów ze znaczącym udziałem pszenicy, zwiększa ryzyko występowania chorób podstawy źdźbła (Paluch i Parylak 2011). W monokulturze zbóż poprawę stanu sanitarnego gleby i w efekcie mniejszy stopień porażenia roślin patogenami wywołującymi choroby podsuszkowe można uzyskać stosując przerywniki $\mathrm{w}$ postaci międzyplonów, a w szczególności z gorczycy białej (Wojciechowski 2005; Parylak i wsp. 2010). Alternatywnym rozwiązaniem jest wykorzystanie biostymulatorów zwiększających odporność roślin na warunki stresowe, a także zastępujących w części chemiczne środki ochrony roślin (Pruszyński 2008; Jaskulski i wsp. 2012). Jednym z takich preparatów organicznych jest Nano-Gro, oparty na mieszaninie siarczanów takich pierwiastków, jak: Fe, Co, Al, Mg, Mn, Ni i Ag (Jankowski i wsp. 2013). Stymulator - zdaniem producenta - powoduje wzbudzanie naturalnej odporności roślin na stres abiotyczny, a w konsekwencji zwiększenie wydajności roślin. Hipoteza badawcza zakłada, że zastosowanie zabiegów o charakterze regeneracyjnym wzmocni kondycję rośliny uprawnej, a w efekcie poprawi się odporność na choroby podstawy źdźbła i zwiększy produkcyjność.

Celem badań była ocena przydatności biostymulatora Nano-Gro oraz międzyplonu z gorczycy białej w ograniczaniu występowania chorób podstawy źdźbła na pszenicy ozimej uprawianej $\mathrm{w}$ monokulturze, a także określenie wpływu tych zabiegów regeneracyjnych na jej plonowanie w warunkach tradycyjnej lub uproszczonej pożniwnej i przedsiewnej uprawy roli.

\section{Materiały i metody / Materials and methods}

Badania zrealizowano w oparciu o ścisłe jednoczynnikowe doświadczenie polowe, które przeprowadzono w latach 2010-2013 w Rolniczym Zakładzie Doświadczalnym Swojec Uniwersytetu Przyrodniczego we Wrocławiu, założone metodą losowanych bloków w trzech powtórzeniach, na poletkach o powierzchni $22 \mathrm{~m}^{2}$, na madzie rzecznej właściwej o słabo wykształconym profilu, wytworzonej $\mathrm{z}$ piasku gliniastego mocnego na utworze z piasku słabo gliniastego, zaliczanej do kompleksu żytniego dobrego, klasy IVa. Czynnikiem badawczym był system uprawy pszenicy ozimej odmiany Trend, na który złożyło się następstwo roślin, zróżnicowanie uprawy roli po zbiorze i przed siewem oraz różne warianty zabiegów regeneracyjnych - wprowadzanie do gleby biomasy międzyplonu ścierniskowego z gorczycy białej, zaprawianie ziarna biostymulatorem lub łączne stosowanie zabiegów. Ziarno zaprawiano preparatem Nano-Gro w ilości 24 granulki/10 1 wody/1 t ziarna. W przypadku pszenicy niezaprawianej biostymulatorem stosowano standardową zaprawę nasienną RaxilGel 206 GF w ilości $500 \mathrm{ml} / 100 \mathrm{~kg}$ ziarna. Po zbiorze przedplonu wykonywano podorywkę na głębokość około $10 \mathrm{~cm}$ albo kultywatorowanie połączone z bronowaniem pielęgnacyjnym. Uprawę przedsiewną realizowano wykonując orkę siewną na głębokość $20 \mathrm{~cm}$ lub z wykorzystaniem agregatu uprawowego. Obiektem kontrolnym była pszenica uprawiana w płodozmianie (rzepak ozimy - pszenica ozima - jęczmień jary), a w przypadku monokultury - z zastosowaniem tradycyjnej, płużnej uprawy roli bez zabiegów regeneracyjnych. Pszenicę, niezależnie od systemu uprawy, wysiewano w ilości $230 \mathrm{~kg} /$ ha. Nawożenie mineralne stosowano w ilości NPK $140-40-60 \mathrm{~kg} / \mathrm{ha}$.

Zainfekowanie źdźbeł i korzeni przez kompleks patogenów powodujących choroby podstawy źdźbła oceniano na 30 losowo wybranych roślinach $\mathrm{z}$ poletka $\mathrm{w}$ fazie BBCH 85. Wydzielono pięć klas porażenia korzeni, gdzie: 0 - zdrowe, $1-1-10 \%$ korzeni porażonych, $2-11-30 \%$ korzeni porażonych, $3-31-60 \%$ korzeni porażonych, 4 powyżej $61 \%$ korzeni porażonych. Dla podstawy źdźbła zastosowano cztery klasy porażenia: 0 - zdrowe, 1 infekcja na odcinku do 1 . kolanka, mniej niż $1 / 2$ obwodu źdźbła zainfekowana, 2 - zakażenie na odcinku do 1 . kolanka, ponad $1 / 2$ obwodu źdźbła zainfekowana, 3 porażenie wchodzi w kolejne międzywęźle. Indeks porażenia obliczono metodą Townsenda-Heubergera (1943). Plony ziarna ustalono $\mathrm{z}$ powierzchni całego poletka. Uzyskane wyniki badań poddano analizie wariancji, a istotność różnic między średnimi oceniano testem t-Studenta na poziomie istotności $\alpha=0,05$. Do określenia związku między stopniem porażenia roślin a plonem ziarna zastosowano analizę korelacji prostej.

\section{Wyniki i dyskusja / Results and discussion}

Stwierdzono istotny wpływ następstwa roślin na stopień porażenia podstawy źdźbła pszenicy ozimej przez kompleks grzybów, będących sprawcami chorób podsuszkowych (tab. 1). Uprawa monokulturowa bez stosowania zabiegów regeneracyjnych doprowadziła do istotnego zwiększenia zainfekowania dolnej części źdźbła o 28,6 punktu procentowego w stosunku do uprawy pszenicy w płodozmianie, co potwierdzają także badania Parylak i Kordasa (2001) oraz Kurowskiego (2002). Adamiak i wsp. (2005) stwierdzili natomiast, że następstwo roślin nie wpływa istotnie na zdrowotność roślin. W badaniach własnych wykazano, że także system uprawy roli w monokulturze wpływa wyraźnie na zdrowotność podstawy źdźbła pszenicy. W warunkach płużnej uprawy roli stwierdzono istotne ograniczenie porażenia źdźbła na poletkach z zastosowaniem biostymulatora [o 17,4 punktu procentowego (p.p.)] i po łącznym zastosowaniu gorczycy białej z preparatem Nano-Gro (o 13,3 p.p.) w porównaniu do monokultury pozbawionej zabiegów regeneracyjnych. Gorczyca i Kasperczyk (2011) twierdzą jednak, że NanoGro nie przyczynia się w praktyce rolniczej do ograniczenia szkodliwości Fusarium. Gdy zastąpiono podorywkę gruberowaniem, istotne zmniejszenie porażenia źdźbeł pszenicy (o 9,9 p.p.) odnotowano tylko po corocznym wprowadzaniu do gleby biomasy gorczycy. Także Parylak (2004) uważa, że uproszczenia uprawy roli wraz z uprawą międzyplonu ścierniskowego prowadzą do niewielkiego zmniejszenia porażenia źdźbeł. $\mathrm{Z}$ kolei 
według Pląskowskiej i wsp. (2002) znaczne ograniczenie zabiegów uprawowych w pszenicy jarej w stosunku do uprawy tradycyjnej nie wpływa na wzrost stopnia porażenia przez patogeniczne grzyby.

Następstwo roślin miało istotny wpływ także na zainfekowanie korzeni pszenicy ozimej przez patogeny wywołujące choroby podsuszkowe (tab. 1). Powtarzana corocznie uprawa pszenicy po sobie spowodowała istotny wzrost porażenia korzeni (o 17,7 p.p.) w porównaniu z płodozmianem. Solarska (2008) potwierdza, że uprawa pszenicy w monokulturze powoduje wzrost zainfekowania systemu korzeniowego zboża. Nie udowodniono natomiast istotnego wpływu czynników fitosanitarnych na zdrowotność korzeni pszenicy ozimej zarówno w warunkach tradycyjnej, jak i uproszczonej uprawy roli. Z kolei w badaniach Wojtali i Parylak (2009) uprawa międzyplonu zmniejszała istotnie porażenie korzeni pszenicy.

Tabela 1. Indeks porażenia roślin przez grzyby powodujące choroby podsuszkowe [\%]

Table 1. Infection index of winter wheat with stem base diseases [\%]

\begin{tabular}{|c|c|c|c|c|c|}
\hline \multirow[b]{2}{*}{$\begin{array}{l}\text { Następstwo roślin } \\
\text { Crop succession }\end{array}$} & \multicolumn{3}{|c|}{ System uprawy - Cropping system } & \multirow[b]{2}{*}{$\begin{array}{l}\text { Źdźbła } \\
\text { Stems }\end{array}$} & \multirow[b]{2}{*}{$\begin{array}{c}\text { Korzenie } \\
\text { Roots }\end{array}$} \\
\hline & $\begin{array}{l}\text { uprawa pożniwna } \\
\text { post-harvest tillage }\end{array}$ & $\begin{array}{l}\text { czynnik fitosanitarny } \\
\text { plant-health factor }\end{array}$ & $\begin{array}{c}\text { uprawa } \\
\text { przedsiewna } \\
\text { pre-sowing tillage }\end{array}$ & & \\
\hline $\begin{array}{l}\text { Płodozmian* } \\
\text { Crop rotation }\end{array}$ & $\begin{array}{l}\text { orka } \\
\text { plough }\end{array}$ & - & $\begin{array}{c}\text { orka } \\
\text { plough }\end{array}$ & 32,0 & 26,3 \\
\hline \multirow{7}{*}{$\begin{array}{l}\text { Monokultura } \\
\text { Continuous crop }\end{array}$} & $\begin{array}{l}\text { orka } \\
\text { plough }\end{array}$ & - & $\begin{array}{l}\text { orka } \\
\text { plough }\end{array}$ & 60,6 & 44,0 \\
\hline & $\begin{array}{l}\text { orka } \\
\text { plough }\end{array}$ & $\begin{array}{c}\text { międzyplon } \\
\text { stubble catch crop }\end{array}$ & $\begin{array}{l}\text { orka } \\
\text { plough }\end{array}$ & 56,6 & 42,6 \\
\hline & $\begin{array}{l}\text { orka } \\
\text { plough }\end{array}$ & $\begin{array}{c}\text { biostymulator } \\
\text { biostimulant }\end{array}$ & $\begin{array}{l}\text { orka } \\
\text { plough }\end{array}$ & 43,2 & 40,7 \\
\hline & $\begin{array}{l}\text { orka } \\
\text { plough }\end{array}$ & $\begin{array}{c}\text { międzyplon + biostymulator } \\
\text { stubble catch crop + biostimulant }\end{array}$ & $\begin{array}{l}\text { orka } \\
\text { plough }\end{array}$ & 47,3 & 42,3 \\
\hline & $\begin{array}{c}\text { gruberowanie } \\
\text { grubber }\end{array}$ & $\begin{array}{c}\text { międzyplon } \\
\text { stubble catch crop }\end{array}$ & $\begin{array}{c}\text { uprawa agregatem } \\
\text { harrow }\end{array}$ & 46,7 & 45,9 \\
\hline & $\begin{array}{l}\text { gruberowanie } \\
\text { grubber }\end{array}$ & $\begin{array}{c}\text { biostymulator } \\
\text { biostimulant }\end{array}$ & $\begin{array}{l}\text { uprawa agregatem } \\
\text { harrow }\end{array}$ & 42,7 & 48,6 \\
\hline & $\begin{array}{c}\text { gruberowanie } \\
\text { grubber }\end{array}$ & $\begin{array}{c}\text { międzyplon + biostymulator } \\
\text { stubble catch crop + biostimulant }\end{array}$ & $\begin{array}{c}\text { uprawa agregatem } \\
\text { harrow }\end{array}$ & 44,8 & 49,8 \\
\hline \multicolumn{4}{|c|}{$\operatorname{NIR}(0,05)-\operatorname{LSD}(0.05)$} & 8,7 & 8,5 \\
\hline
\end{tabular}

*rzepak ozimy - pszenica ozima - jęczmień jary; winter oilseed rape - winter wheat - spring barley

Tabela 2. Plon ziarna pszenicy ozimej

Table 2. Grain yield of winter wheat

\begin{tabular}{|c|c|c|c|c|}
\hline \multirow{2}{*}{$\begin{array}{l}\text { Następstwo roślin } \\
\text { Crop succession }\end{array}$} & \multicolumn{3}{|c|}{ System uprawy - Cropping system } & \multirow[b]{2}{*}[\mathrm{t}/\mathrm{ha}]{} \\
\hline & $\begin{array}{l}\text { uprawa pożniwna } \\
\text { post-harvest tillage }\end{array}$ & $\begin{array}{l}\text { czynnik fitosanitarny } \\
\text { plant-health factor }\end{array}$ & $\begin{array}{l}\text { uprawa przedsiewna } \\
\text { pre-sowing tillage }\end{array}$ & \\
\hline $\begin{array}{l}\text { Płodozmian* } \\
\text { Crop rotation }\end{array}$ & $\begin{array}{c}\text { orka } \\
\text { plough }\end{array}$ & $\mathrm{r}$ ( & $\begin{array}{c}\text { orka } \\
\text { plough }\end{array}$ & 5,27 \\
\hline \multirow{7}{*}{$\begin{array}{l}\text { Monokultura } \\
\text { Continuous crop }\end{array}$} & $\begin{array}{l}\text { orka } \\
\text { plough }\end{array}$ & - & $\begin{array}{l}\text { orka } \\
\text { plough }\end{array}$ & 4,62 \\
\hline & $\begin{array}{l}\text { orka } \\
\text { plough }\end{array}$ & $\begin{array}{c}\text { międzyplon } \\
\text { stubble catch crop }\end{array}$ & $\begin{array}{l}\text { orka } \\
\text { plough }\end{array}$ & 4,46 \\
\hline & $\begin{array}{l}\text { orka } \\
\text { plough }\end{array}$ & $\begin{array}{c}\text { biostymulator } \\
\text { biostimulant }\end{array}$ & $\begin{array}{l}\text { orka } \\
\text { plough }\end{array}$ & 4,37 \\
\hline & $\begin{array}{c}\text { orka } \\
\text { plough }\end{array}$ & $\begin{array}{c}\text { międzyplon + biostymulator } \\
\text { stubble catch crop + biostimulant }\end{array}$ & $\begin{array}{l}\text { orka } \\
\text { plough }\end{array}$ & 4,68 \\
\hline & $\begin{array}{c}\text { gruberowanie } \\
\text { grubber }\end{array}$ & $\begin{array}{c}\text { międzyplon } \\
\text { stubble catch crop } \\
\end{array}$ & $\begin{array}{l}\text { uprawa agregatem } \\
\text { harrow }\end{array}$ & 4,10 \\
\hline & $\begin{array}{c}\text { gruberowanie } \\
\text { grubber }\end{array}$ & $\begin{array}{c}\text { biostymulator } \\
\text { biostimulant }\end{array}$ & $\begin{array}{l}\text { uprawa agregatem } \\
\text { harrow }\end{array}$ & 3,79 \\
\hline & $\begin{array}{c}\text { gruberowanie } \\
\text { grubber }\end{array}$ & $\begin{array}{c}\text { międzyplon + biostymulator } \\
\text { stubble catch crop + biostimulant }\end{array}$ & $\begin{array}{c}\text { uprawa agregatem } \\
\text { harrow }\end{array}$ & 4,01 \\
\hline \multicolumn{4}{|c|}{$\operatorname{NIR}(0,05)-\operatorname{LSD}(0.05)$} & 0,54 \\
\hline
\end{tabular}

*rzepak ozimy - pszenica ozima - jęczmień jary; winter oilseed rape - winter wheat - spring barley 


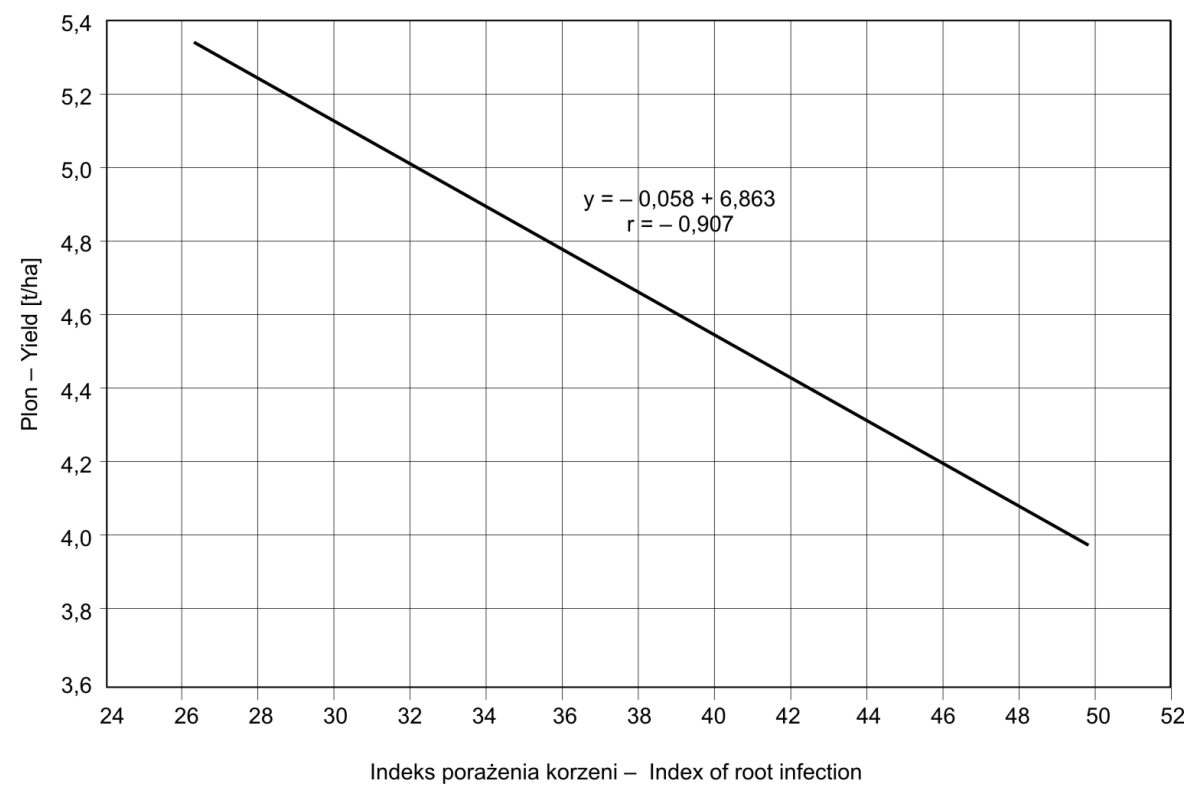

Rys. 1. Korelacja między stopniem porażenia korzeni przez grzyby wywołujące choroby podsuszkowe a plonem ziarna pszenicy ozimej Fig. 1. Correlation between index of root infection and grain yield of winter wheat

Powtarzana uprawa pszenicy spowodowała istotne ograniczenie plonu ziarna o $12,3 \%$ (tab. 2). Lemańczyk (2002), Woźniak (2006) oraz Buraczyńska i Ceglarek (2008), potwierdzili, że niekorzystny przedplon powoduje wyraźny spadek plonu zboża. W systemie płużnym nie stwierdzono jednak istotnego wpływu zabiegów regeneracyjnych na produkcyjność pszenicy w porównaniu do monokultury bez stosowania zabiegów fitosanitarnych. Doležal (2010) natomiast donosi, że zaprawienie NanoGro materiału siewnego zarówno rzepaku, jak i jęczmienia wpływa na istotną poprawę plonowania roślin. Matysiak i Kaczmarek (2008) po zastosowaniu preparatu Kelpak obserwowały wzrost plonu ziarna pszenicy. Z kolei w warunkach uproszczonej uprawy roli pogorszyła się skuteczność biostymulatora oraz łącznego zastosowania zabiegów regeneracyjnych odpowiednio o 13,3 i 14,3\% w stosunku do tych samych zabiegów stosowanych w systemie płużnym. Malarz i wsp. (2008) oraz Przybysz i wsp. (2008) twierdzą natomiast, że im roślina narażona jest na dłużej trwający stres, tym większa skuteczność biostymulatorów w stabilizacji plonu. Matysiak i Kaczmarek (2008) oraz Grzyś (2012) uważają, że skuteczność działania biostymulatorów jest uzależniona także od sposobu dostarczenia ich roślinie.

Stwierdzono istotną zależność między zdrowotnością korzeni a plonem ziarna pszenicy (rys. 1). Plon był ujemnie skorelowany ze stopniem porażenia korzeni. Wzrostowi indeksu porażenia korzeni o $1 \%$ towarzyszył spadek plonu o 0,06 t/ha. Z kolei Wojtala i Parylak (2009) nie stwierdziły istotnej zależności między stopniem porażenia korzeni a masa ziarna. W badaniach własnych nie wykazano istotnej korelacji między indeksem porażenia podstawy źdźbła a plonem ziarna $(\mathrm{r}=-0,204)$.

\section{Wnioski / Conclusions}

1. Porażenie źdźbeł i korzeni pszenicy ozimej odmiany Trend uprawianej w monokulturze przez kompleks patogenów wywołujących choroby podstawy źdźbła było istotnie większe, a plon ziarna o $12,3 \%$ mniejszy niż w płodozmianie (rzepak ozimy - pszenica ozima jęczmień jary).

2. W warunkach tradycyjnej uprawy roli zaprawianie ziarna biostymulatorem Nano-Gro oraz łączne stosowanie tego preparatu z corocznym przyorywaniem międzyplonu ścierniskowego z gorczycy białej przyczyniło się do istotnego ograniczenia porażenia podstawy źdźbła odpowiednio o 28,7 i 21,9\% w porównaniu z monokulturą, w której nie stosowano zabiegów regeneracyjnych. $Z$ kolei po uproszczeniu uprawy roli wyłącznie wprowadzenie do gleby biomasy międzyplonu spowodowało redukcję porażenia podstawy źdźbła (o 17,5\%).

3. Stopień porażenia systemu korzeniowego na ogół nie zależał od sposobu uprawy roli i zabiegów regeneracyjnych, natomiast stwierdzono wyraźną zależność plonu ziarna od stopnia porażenia korzeni pszenicy.

\section{Literatura / References}

Adamiak E., Adamiak J., Balicki T. 2005. Wpływ wieloletniej monokultury na występowanie chorób podstawy źdźbła w czterech zbożach. Fragmenta Agronomica 22 (2): 7-13.

Burczyńska D., Ceglarek F. 2008. Plonowanie pszenicy ozimej uprawianej po różnych przedplonach. Acta Scientarum Polonorum Agricultura 7 (1): 27-37. 
Doležal J. 2010. NANO-GRO® - pomocný rostlinný př́ípravek - levná, přírodní a jednoduchá metoda zvyšování zemědělské produkce bez použití syntetických chemických sloučenin. Sborník z konference „Prosperující olejniny 2010“: 133-135.

Gorczyca A., Kasperczyk M. 2011. Initial research on the effect of the Nanogro plant growth stimulator on Fusarium culmorum (W.G. Smith) Sacc. Ecological Chemistry and Engineering A 18 (12): 1625-1632.

Grzyś E. 2012. Wpływ wybranych substancji biologicznie czynnych na kukurydzę uprawianą w warunkach stresu. Wydawnictwo Uniwersytetu Przyrodniczego we Wrocławiu, Monografie 145, 101 ss.

Jankowski K., Deska J., Truba M., Jankowska J. 2013. Impact on Nano-Gro stimulator on the seeds germination and growth kinetics of seedlings of selected grass and legumes species. Ochrona Środowiska i Zasobów Naturalnych - Environmental Protection and Natural Resources 24 (1): 23-26.

Jaskulski D., Kotwica K., Jaskulska I., Piekarczyk M., Osiński G., Pochylisk G. 2012. Elementy współczesnych systemów uprawy roli i roślin - skutki produkcyjne oraz środowiskowe. Fragmenta Agronomica 29 (3): 61-70.

Kurowski T. 2002. Studia nad chorobami podsuszkowymi zbóż uprawianych w wieloletnich monokulturach. Wydawnictwo Uniwersytetu Warmińsko-Mazurskiego w Olsztynie, Monografie 56, 86 ss.

Lemańczyk G. 2002. Wpływ zróżnicowanych przedplonów na zdrowotność podstawy źdźbła pszenicy ozimej uprawianej na glebie dobrego kompleksu pszennego. Acta Scientarum Polonorum Agricultura 1 (1): 111-119.

Malarz W., Kozak M., Kotecki A. 2008. The use of Asahi SL biostimulator in spring rape growing. p. 25-32. In: "Biostimulators in Modern Agriculture. Fields Crops" (Z.T. Dąbrowski, ed.). Wieś Jutra, Warszawa, 118 pp.

Matysiak K., Kaczmarek S. 2008. Potential advantages of Kelpak bioregulator applied to some field crops. p. 99-106. In: „Biostimulators in Modern Agriculture. Fields Crops” (Z.T. Dąbrowski, ed.). Wieś Jutra, Warszawa, 118 pp.

Paluch M., Parylak D. 2011. Wpływ zabiegów proekologicznych w monokulturze pszenżyta ozimego na ograniczenie porażenia przez choroby podsuszkowe. [Effect of eco-friendly measures in winter triticale monoculture on the reduction of infection by steam base diseases]. Progress in Plant Protection/Postępy w Ochronie Roślin 51 (3): 1328-1332.

Parylak D. 2004. Possibilities of root and stem base diseases limitation in continuous wheat under conventional tillage and no-tillage system. Journal of Plant Protection Research 44 (2): 141-146.

Parylak D., Kordas L. 2001. Wpływ czynników agrotechnicznych na porażenie pszenicy ozimej przez zgorzel podstawy źdźbła (Gaeumannomyces graminis). [The effect of agronomical factors on take all (Gaeumannomyces graminis) infestation of winter wheat]. Progress in Plant Protection/Postępy w Ochronie Roślin 41 (2): 762-765.

Parylak D., Paluch M., Wojtala-Łozowska L. 2010. Ocena możliwości ograniczania porażenia pszenżyta ozimego uprawianego po sobie przez choroby podstawy źdźbła. [Possibilities of stem base diseases limitation in winter triticale continuous crop]. Progress in Plant Protection/Postępy w Ochronie Roślin 50 (2): 695-699.

Pląskowska E., Matkowski K., Moszczyńska E., Kordas L. 2002. Zdrowotność podstawy źdźbła pszenicy jarej w uprawie tradycyjnej i siewie bezpośrednim przy dwóch poziomach nawożenia azotem. Acta Scientarum Polonorum Agricultura 1: 131-138.

Pruszyński S. 2008. Biostimulators in plant protection. p. 18-23. In: "Biostimulators in Modern Agriculture. General Aspect" (H. Gawrońska, ed.). Wieś Jutra, Warszawa, 89 pp.

Przybysz A., Małecka-Przybysz M., Słowiński A., Gawrońska H. 2008. The effect of Asahi SL on growth, efficiency of photosynthetic apparatus and yield of field grown oilseed rape. p. 7-17. In: "Biostimulators in Modern Agriculture. Field Crops" (Z.T. Dąbrowski, ed.). Wieś Jutra, Warszawa, $118 \mathrm{pp}$.

Solarska E. 2008. Określenie przyczyn chorób korzeni pszenicy ozimej uprawianej w różnych systemach produkcji. Postępy Nauk Rolniczych 531: 201-210.

Starczewski J., Czarnocki S., Turska E. 2004. Alternatywne sposoby uprawy roli i ich ekonomiczna ocena. Annales Universitatis Mariae Curie-Skłodowska, Sectio E, Agricultura 59: 277-284.

Townsend G., Heuberger J. 1943. Methods for estimating losses caused by diseases in fungicide experiments. Plant Disease Report 27: 340-343.

Wojciechowski W. 2005. Oddziaływanie przyorywanych międzyplonów ścierniskowych i nawożenia azotem na zdrowotność roślin pszenicy jakościowej. [The effect of ploughing down stubble crops and nitrogen fertilization on health status of quality wheat]. Progress in Plant Protection/Postępy w Ochronie Roślin 45 (2): 1197-1199.

Wojtala L., Parylak D. 2009. Skuteczność zapraw nasiennych, międzyplonu i poziomu nawożenia azotowego w ograniczaniu porażenia pszenicy ozimej przez patogeny podstawy źdźbła. [Effectiveness of seed treatment, stubble crop and level of nitrogen fertilization in reducing winter wheat infection with root and stem base pathogens]. Progress in Plant Protection/Postępy w Ochronie Roślin 49 (2): 769-772.

Woźniak A. 2006. Wpływ przedplonów na plon i jakość ziarna pszenicy ozimej. Acta Scientarum Polonorum Agricultura 5 (2): $99-106$. 